\title{
A Critical Assessment of Community-Based Tourism Practices in Nglanggeran Ecotourism Village, Indonesia
}

\author{
Rucitarahma Ristiawan ${ }^{1^{*}}$, Guillaume Tiberghien ${ }^{2}$ \\ ${ }^{1}$ Tourism Studies Program, Faculty of Cultural Sciences, Universitas Gadjah Mada, Indonesia \\ ${ }^{2}$ School of Interdisciplinary Studies, University of Glasgow, Crichton University Campus, Dumfries, Scotland
}

\begin{abstract}
This study investigates the strategic managerial practices to overcome the developmental challenges of CBT in the Nglanggeran Ecotourism Village in Yogyakarta, Indonesia. It evaluates, in particular, the CBT impacts on community economic well-being, socio-cultural development, and environmental sustainability. A qualitative case study approach based on semi-structured interviews with key stakeholders involved in the planning and development of the village was employed to assess the benefits and challenges of CBT practices and their compatibility with sustainable community development. Results indicate that despite new employment opportunities and an increase in environmental conservation efforts, CBT planning and development in the village led to unequal distribution of economic benefits induced by conflicts within the community, uneven participation opportunities of the local community in tourism, and incompatibility in fulfilling individual's need for sustainable community development.
\end{abstract}

Keywords: CBT Practices, Ecotourism Village, Sustainable Community Development.

\section{INTRODUCTION}

The concept of Community-Based Tourism (CBT) has arisen as a prominent term in developing countries' tourism that centres on the involvement of the host community in planning and maintaining tourism development to create a more sustainable ecotourism industry [1]. It is argued that the development of CBT in developing countries is mostly initiated by the community, although also supported by external aid both for technical or financial support $[2,3]$. On the other hand, the development of CBT in ecotourism raises questions related to its managerial practices, including increasing social unrest, lack of local tourism business knowledge and training, and pseudo-participation of the local communities in the tourism planning $[4,5]$. CBT, as part of the sustainable community development agenda, occasionally ignores the heterogeneous state of the local community consisting of individuals with various economic, socio-cultural, and environmental needs, which can result in a lack of community control to meet individual needs $[6,7]$.

Community-based development in the Indonesian tourism context is directly shaped by the international agenda [8]. Historically, Indonesia grew its international tourism industry since the late 1960s with assistance from the World Bank and other international support

*Correspondence address:

Rucitarahma Ristiawan

Email : Rucitarahma Ristiawan

Address : Faculty of Cultural Sciences, Universitas Gadjah Mada, Bulaksumur 55282
$[8,9,10]$. In 2012, the Indonesian central government launched a new strategic plan for sustainable tourism as a basis for tourism development. This new strategic plan directly enhanced the community-based development agendas in several major tourism destinations in Indonesia, including Yogyakarta [11]. The plan encouraged tourism village development as one of the national tourism development projects in Indonesia with regard to community empowerment and environmental sustainability [12]. Yogyakarta, with its natural and cultural resources, appeared as an ideal area to plan a tourism village that could enhance local community empowerment $[13,14,15]$. In the same vein, the Nglanggeran Ecotourism Village was developed in 1999, and within a few years received the award of the best ASEAN sustainable tourism village in South-East Asia [16]. However, despite the prominent and efficient model of management of local tourism, the new CBT village strategy has induced sociocultural, economic, and environmental impacts in the local context that need to be further assessed.

To this end, the overall aim of this study is to investigate the economic, social, cultural, and environmental dimensions of the benefits and challenges of CBT development in the context of Nglanggeran Ecotourism Village in Yogyakarta. It evaluates, in particular, the strategic managerial practices to overcome the challenges of $C B T$ development in the village, in particular the CBT impacts on community economic well-being, socio-cultural development, and environmental 
sustainability. By examining CBT impacts across these four dimensions, this research provides a critical evaluation of whether CBT practices in the context of the village meet the sustainable community development criteria and lead to local planning and development.

\section{Community-Based Tourism in Benefiting and Challenging Community}

A range of disciplines has used communitybased approaches in extending their development-related discussion, for example, environmental conservation [17], urban and rural development [18], and tourism $[19,20]$. In the tourism context, CBT can be perceived as an example of a bottom-up planning approach [4] and emerged as a prominent strategy in poverty reduction, focusing on ownership and the decision-making power of the local community resulting in some positive impacts on the local community [21]. A number of previous studies have debated the impacts of CBT in terms of economic impact [22], socio-cultural impact $[23,24]$, and environmental impact [3]. CBT practices can be beneficial for the local community by enabling more community opportunities for participating and gaining benefits from tourism activities, reducing economic leakage, and increasing the environmental sustainability awareness of both locals and visitors [2]. The higher the community participation level, the more benefits are received by the local community [22]. Local community involvement in tourism activities can also result in the increase of a more even income distribution from tourism activities towards the local community [19].

In contrast, the development of CBT can also create some challenges for the local community, including the potential increase in peasant differentiation and unrest, unequal local community involvement in the decision-making processes, and the restructuring of work and of time that is involved in introducing a new activity [4]. Matters of criticism of CBT include the need to put CBT as a community's shared knowledge assuming community as a homogenous entity [25] to address the power relations within the community as well as varied capital of each individual in the control of local tourism development $[1,26]$ as means to secure personal benefits from tourism, questioning what influences the individuals' ability to engage in tourism $[7,26]$.
In practice, $\mathrm{CBT}$ has often benefited the more powerful within a community and failed to involve all residents [27], which may cause the local community to develop a negative attitude towards tourism that significantly influences the profitability of the industry [28]. In that case, CBT can encourage unequal benefits distribution as the benefits from tourism activities are mostly received by some local elites and individuals who have dominant power in deciding the development direction of tourism [7]. Furthermore, the tourist industry's conceptualisation of community may ignore the heterogeneous state of the community and how community groups can act out of self-interest rather than for the collective good [29], leading to outcomes that build exclusive club capital instead of inclusive social capital [1]. CBT is also assumed to be a high-cost project in which local empowerment is perceived as adding to the cost of doing business or as irrelevant to the earning of profit [30]. It can result in community irritation and changing the 'openness attitude' of residents towards tourism for not being involved in the tourism development surrounding their areas [31].

Culturally, CBT practices that promote local traditional cultural resources may lead to a higher commodification of culture. Commodifying local cultural resources potentially generate more income for the local community through transactional activities in providing cultural attractions for tourists [32]. These commodification practices enhance the community's identity re-building through culture touristification processes [33]. This economicdriven cultural activity can enhance the appearance of a new identity of the community in the context of tourism cultures [34]. However, commodifying local cultures as tourists' attraction can result in the loss of sacredness of the community's cultural practices and beliefs. Culture commodification can generate new roles for artisans and objects based on the economic tendency in tourism development activities [35,32].

On the other hand, the commodification of culture can influence how a community perceives its culture as a commodity, changing community's living patterns in utilising their cultural products as a new economic resource $[13,36]$ that can change visitors' perception of authenticity of the toured objects and the hostguest relationship [37,38] and reduce tourists' experience and satisfaction [36]. This results in a 
cultural clash between local communities and tourists and appears as one of the most important challenges in managing and planning the cultural dimension of community-based tourism in rural areas [26].

\section{Tourism and Sustainable Community Development}

Empowerment of local people, self-reliance, and social justice are increasingly considered important elements in contemporary debates about sustainable development [39]. Therefore, it is important to look at a form of sustainable community development that balances economic benefits from development with political, cultural, and environmental tensions within communities [40] through assessing five sustainable community development principles: economic self-reliance, ecological sustainability, community control, meeting individual needs and building a community culture [41]. Economic selfreliance aims to increase the internal strength of a community by enhancing its supply of local wealth to fulfil community needs and retain community wealth through local-based development resources. Collective self-reliance works to build the internal strengths of a community and is a strategy to avoid exploitation and domination of one party over another. Localbased development should be ecologically sensitive, considering the inextricable relation of ecology as an important part of human nature, and consider the sustainable use of ecological resources [40]. Tourism as a community development tool should emphasis the larger scale productive activities in its development practices by emphasising the importance of environmental conservation [3].

The community control aspect of sustainable community development principles emphasises the ability of a community to gain more power and control over its development decisionmaking [42]. Community control, therefore, depends on the power-sharing within community members based on bonding, networking, and coalition building [40]. Enabling a community to gain greater ability in shaping its own future and meeting the individual needs, therefore, appears as the main objective of tourism development practices [44]. The strategy to rebuild and revitalise a community should consider the emotional and physical well-being of its individuals as the main factors impacting a community's long-term social, economic, and spiritual health [42]. Moreover, through enabling cooperation with other stakeholders such as government and academics, community can be the main controller of their own development progress [24,43]. The multiple stakeholder approach in developing a tourism village enables the local community to gain equal opportunities in deciding their own developmental direction [14].

Lastly, community cultural identity building emphasises the development practices that sustain community identity, purpose, and culture to achieve common community objectives [34]. A common identity, purpose, and culture appear as the basis of a communities' ability to sustain itself over generations [41]. In contrast, tourism development can transform a community's identity influenced by how tourists perceive them, which potentially influences their perception of being a rural resident and living a rural life [32]. By transforming the community's identity, tourism can provide a new platform through which identity can be managed, represented, and rebuilt [34]. This new identity formation is typically grounded in the representations of local cultures, traditions, and values of heritage that have little to do with the socio-economic conditions of tourist destinations [45].

\section{RESEARCH METHODOLOGY}

This research employed a qualitative case study focus [46] commonly used to consider tourism impacts on community development as a social phenomenon [47]. The case study method can be used to assess community tourism development practices as the method enable deep examination of a specific social phenomenon using the particularity of the selected case [46]. The researchers used a withinsite single case study approach with one selected location [48] to explore the potential and challenges of CBT in the village, its social, cultural, and economic impacts, as well as the compatibility of CBT practices with sustainable community development principles. A single case study can be used to critically assess and test a well formulated theory [46], and the Nglanggeran Ecotourism Village provided a unique account as the first Geopark site in Indonesia certified by UNESCO (2017) and the best tourism village in South-East Asia [16].

\section{Data Collection}

In-depth semi-structured interviews using thirteen open-ended questions with twelve participants were employed to gain detailed 
insights into CBT practices and tourism development in the village. Participants were selected and interviewed in July 2017 using a purposive sampling strategy as key stakeholders involved in the planning and development of the village, encompassing the head of the tourism organisation, the marketing coordinator, the secretary of the tourism village management, the coordinator of the development of the local community tourism organisation and the coordinator of the activities of local community tourism organisation. To ensure fair local community participation in tourism activities, the local community tourism organisation created some groups consisting of local community members. These groups are responsible for managing specific tourism development tasks based on their abilities and competency, for instance, the farmers' group is responsible for managing agritourism activities, the culinary group for managing the local culinary products and hygiene, and the homestay group for organising and maintaining a high standard of homestay for the tourists. Structurally, these later groups are under the supervision of the local community tourism organisation. Table 2 describes the informants and their occupation roles in relation to the tourism management of the Nglanggeran Ecotourism Village.

The study employed a theory-driven thematic analysis [49] methodology to analyse the data which splits the process into three stages. At the first stage of analysis, the issues (the economic, socio-cultural, and environmental impacts of tourism) related to the CBT benefits and challenges in Nglanggeran Ecotourism Village were decided and designed. Codes from the theoretical framework (CBT impacts on the local community and sustainable tourism development principals) were then generated through review and rewriting and applied to categorise the raw information to determine their reliability. The codes resulting from stage two were applied to the raw information in a third stage. The researchers then interpreted and connected the coded data in the context of the conceptual framework to generate the main themes (such as employment opportunities and increase in environmental conservation efforts induced by $\mathrm{CBT}$ ) that are detailed in the subsequent sections. Results were finally compared with empirical data as a means to make the findings and conclusions credible.

\section{RESEARCH RESULT}

CBT in Impacting Community Economic Aspects

CBT development in the Nglanggeran Ecotourism Village directly generated the development of new productive-economy enterprises such as local homestays, traditional culinary services, and the production of art and cultural performances, souvenirs, and handicrafts. It also enabled some new job opportunities in guiding and organising tours, security services, and promotional activities. Although the benefits varied as they depended on the actual participation of community members, CBT was argued by the head of local community tourism organisation to increase the community members' monthly income by about IDR 800.000 - IDR 1.500.000, almost equal to a monthly standard salary. Taking into account CBT was only a modest alternative source of income at the beginning of its development, this new revenue was considered a considerable amount of income by local community members. As stated by a homestay provider:

"In the beginning, we only relied on income from agricultural products. Now, with the actual practices of tourism, it does not mean that we quit being farmers. We can still run our farming activities, but they have to be integrated with tourism activities."

However, considering the diverse amount of income individuals received from their participation in tourism activities, the role of human capital in determining job provision in the village produced uneven wealth distribution within the community that created conflicts within the community. As stated by one of the local tour guides, having less opportunity for participating in tourism activities induced some internal conflicts in the village:

"We consider that every community member has different capabilities so we cannot directly involve them in every tourism activity. They receive different income that depends on the participation of each individual in the activities. Some people would say that it is unequal, even some others become angry and protest."

Additionally, several external investors from Surabaya and Jakarta in Indonesia aimed to buy the locals' lands because as they were seen as an opportunity for developing tourism enterprises such as homestays and restaurants. The local communities in Nglanggeran Tourism Village were resistant in retaining their land as they realised that the ownership of their land and properties were important in supporting local tourism development. 


\section{CBT: Impacting Social Life of Community}

After being introduced in late 2008, CBT in Nglanggeran Tourism Village directly impacted social relationships among community members. The coordinator of activities of the local community tourism organisation argued that the management of the tourism village aimed at including all community members to actively contribute to tourism development by involving them with tasks compatible with their managerial abilities:

"We can maximise the level of local community participation and local development as each task is managed by 'capable' locals. We also held regular pieces of trainings with local community members to give them basic knowledge regarding tourism development as a means to maximise benefits and limit the negative impacts of tourism."

CBT development contributed to reducing the number of local community members working outside the village as more job availability also decreased the numbers for juvenile delinquency and unemployment, increased the sense of togetherness and harmony of the local community, and raised the security in the area. Presently, there are only a few local community members who work in foreign countries as labourers. More job availability also reduces the juvenile delinquency level as they can use their time for working in tourism activities instead of being involved in criminal activity.

CBT practices also encouraged community participation in tourism including night activities, for example, walking to the top of the mountain, night gatherings, and bonfire performances as well as seeing night art performances such as Wayangan (leather puppet performances) that usually last until midnight. However, these activities disturbed the resting time of some community members, as stated by the head of the village government officials:

"Some people in the village were complaining to me when there are some performances in the night which disturb their resting time. I am aware of the negative responses of some communities, and they potentially can lose their sense of welcome along with the further development of tourism activities."

Moreover, the uneven participation opportunities resulting from the way the local community tourism organisation hired local community members based on their competencies, knowledge, skills, and abilities enhanced uneven job distribution, leading to conflicts within the community. Not all community members can accept that the benefits of tourism activities in the village cannot be received instantly and are not easily accessible for some members of the village. We thus must mediate some conflicts within local community members. A local tour guide state that:

"We found that making all community members participate equally in the industry is a hard thing to do, but we should make a greater effort in that direction."

An additional social challenge of CBT also emerged regarding the difficulty to make the community understand CBT as their shared knowledge, resulting in low development progress. Community members have their own perspectives of tourism development activities in this village. Some individuals do not want to be involved in tourism activities as, for them, their current activities such as farming and gardening can generate more income. Regardless of the local tourism organisation efforts in persuading some community members to be involved in tourism activities, the consensus around the development objectives seems hard to achieve in that every individual of the community had different perspectives for the development of tourism in the village. It was highlighted by the secretary of the local community tourism organisation, who considered this situation as an obstacle in ecotourism village development:

"We tried to persuade them by continuously holding public meetings and workshops as well as personal approaches for those who were still reluctant to participate. Most of them can now actively contribute to tourism development in this village although there are some individuals who still refuse to be involved in tourism activities."

Through continuous personal development and local-based training, the local community tourism organisation managed to have more local community members actively contributing to tourism village activities.

\section{CBT and the Dynamics of Community Cultural Aspect}

In the need to deliver more authentic experiences and based on the consideration that $>80 \%$ tourist visiting Yogyakarta are motivated by cultural attractions offered [50], the community resurrected their ancient arts and culture performances as tourism attractions and educated their children in their performance. Such learning-teaching activity induced a form of knowledge transfer and expanded the collective memory of an ancient culture that was projected 
to sustaining the community's culture for further purpose.

However, some informants detailed that tourists' culture could also possibly bring negative impacts towards the local community's culture. A member of a local youth organisation stated that the community members were aware of acculturation and cultural shock provided by tourism activities:

"Tourists bring their own cultures which are different to our culture and custom, for instance, how they are dressed that is totally different to our custom and culture. We are aware that it can influence the community's culture, particularly for our young generation."

Interestingly, the tourism culture directly influenced the local community perspectives in strengthening their identity as a homestay provider emphasised the cultural opportunities created by such tourism culture:

"We can positively respond to it by strengthening our own culture. We can give an understanding to the tourists of what should or should not be done when they do activities referring to our culture and local wisdom. Surprisingly, the great willingness from tourists to accept our cultural rules and norms shows our willingness in conserving our culture and retaining our identity."

Commodifying the locals' cultural practices into tourism attractions encouraged the community's collective memories resulting in stronger local identity within cultural assimilation processes between host and guest. In attending the cultural attractions, the tourists were also forced to be active participants in the performances to enhance the traditional experience they got from visiting the village.

\section{CBT and Its Environmental Impacts for Locals}

The head of the farmer group of Nglanggeran Ecotourism Village argued that at the beginning of tourism activities in Nglanggeran, tracking and walking activities provided for tourists decreased the number of endemic fauna such as long-tailed monkey (Macaca fascicularis) and Javanese eagle (Nisaetus bartelsi), as well as the harming natural environment because of the rubbish brought by visitors.

"Tourism activities decreased the number of Javanese eagles and long-tailed monkeys who have been living here for a long time, even the eagles have disappeared and cannot be seen anymore. We also get a lot of rubbish coming from irresponsible visitors. We decided to change our development strategy. We established an ecotourism area based on our environment and community developments' interests. We use our environmental resources as tourist attractions with sound consideration for environmental sustainability in the area. We offered conservation activities as tourists' attraction to gain more environmental understanding for locals and tourists."

CBT practices in the village directly enhanced the conservation efforts of the local community. Along with tourism development and the rise of concern for environmental sustainability, the organisation provided conservation activities as attractions offered to tourists. By branding themselves as an ecotourism village, the local community tourism organisation increased the prices of attractions and targeted more mature visitors (25-50 years old) with high income and high purchasing power from the big cities of Java as the new market segment, as revealed by the development coordinator of the local community tourism organisation:

"We consider that the village's visitation number has increased year by year so it could damage the natural environment surrounding the village. We decided to increase the ticket price and target high-income visitors as our new market. By using these strategies, we were able to decrease the tourists' number by 21 $\%$ and $27 \%$ in 2015 and 2016 respectively and multiply income up to IDR 100.000.000 (f5277) and IDR 180.000.000 (E9499) in 2015 and 2016, respectively."

This new segmentation strategy deployed by the local community tourism organisation directly influenced the visitation number and income the organisation received.

\section{Projecting CBT Development through Sustainable Community Development Lens}

Existing practices of CBT in Nglanggeran Ecotourism Village encouraged the local community to be more independent economically. The income individuals received from tourism activities directly supported their abilities to fulfil daily needs. Presently, all service providers, including homestay providers, culinary providers, and tour guides in Nglanggeran Village, are locals. Community members have more opportunities in developing new products based on local resources, such as chocolate and batik (traditional Javanese clothes), and to be more independent in gaining economic benefits from tourism that supported their daily needs through CBT development.

In terms of environment conservation aspect, by enabling the development of CBT in the village, all respondents argued that the conservation efforts in Nglanggeran Ecotourism Village were increasing. The local tourism 
organisation also puts on conservation activities as tourist attractions considering the added economic value of eco and green terms, as stated by the coordinator of development of local community tourism organisation:

"We realise that 'eco' and 'green' terms are an important tagline in promoting environmental-based tourism in the village. However, we also have a responsibility to provide comprehensive explanations regarding environmental resources and the benefits of ecological conservation to make the tourists more aware of the importance of protecting the environment."

The transformation of the village induced by tourism also enhanced the community's positive participation in sustainably developing their village. Conservation activities directly increased community members' environmental concern, as stated by a homestay provider:

"We are more aware of the need for having a proactive attitude towards environmental sustainability in the village. We created the Clean Friday tagline along with the local youth organisation to make it mandatory for community members to regularly, once in a week, clean their surrounding environment so the view of our village will always be good in the eyes of the tourists."

Conservation activities included in their tourism packages offered to visitors, for instance, planting trees and releasing and spreading fish seed in the river, directly increased environmental concern within community members. Besides, all activities and enterprises in Nglanggeran Tourism Village are based on local ownership in that local community members directly control their assets, determining the long-term welfare of a community [41]. The local community tourism organisation also accommodates community members' aspirations, critiques, and evaluations regarding tourism development in the village by providing regular meetings (Selasa Kliwon Forum) for evaluating the progress of tourism development in the village. The organisation also had several modes of cooperation with external parties, for example, NGOs, local regional government, academics and tour operators. A local tour guide further argued that these external relationships essentially supported the community development effort:

"We have cooperated with many stakeholders including UNESCO in developing the management plan of this village as a part of Gunung Sewu Geopark site assisted by academics from University Gadjah Mada. We also received funds from the Indonesian Ministry of Tourism to build new facilities including toilets, signage, and building a Joglo (Community Centre) as a hub for community activities. We also cooperated with tour operators mainly from Yogyakarta, Jakarta, and Bali to promote our natural and cultural attractions."

Collaborations between local community tourism organisations with these tourism stakeholders external to the village were intended to develop the village's tourism attractions and community members' capability in managing tourism development. Considering the various motivations of stakeholders involved in tourism development, the local community tourism organisations made clear the extent to which the stakeholders could cooperate with them, as stated by the head of the farmers' group:

"We understand that each stakeholder has his or her own importance for cooperating with us. We always negotiated each project before agreeing to cooperate. It is fine if the projects are beneficial and do not provide any negative impacts on the local community. All the projects can support the development of tourism by assisting us in creating a management plan and helping us in building new facilities so that the tourists can use them."

The success of the collaborations between various stakeholders thus depended on how the community-controlled the progress of tourism development in the village. Also, the success of CBT depends heavily on to what extend CBT can enable the locals to meet their individual needs. The local community tourism organisation in Nglanggeran Ecotourism Village encouraged the development process of the village by classifying and clustering community members into several groups. This attempt caused internal community conflicts as it meant individuals with less or unmatched cultural capital could not efficiently participate in tourism development, as revealed by the head of local youth organisation:

"Some individuals cannot be included in tourism activities because they have no skills in managing specific tourism activities. They are low educated individuals. We try to persuade them to do easy tasks such as securing the parking area but they claim it is not enough to make a living. They did some protests resulting in conflicts within community members but we managed that situation using dialogue and mediation."

Moreover, several community members have protested as the practices of tourism development largely only focused on two hamlets (Nglanggeran Kulon and Nglanggeran Wetan), which implied that the three other hamlets' community members were receiving 
fewer benefits from tourism development, as argued by the head of the village government officials:

"The benefit distribution is unequal within the five hamlets. Most members of the Local Community Tourism Organisation are from Nglanggeran Kulon and Nglanggeran Wetan. There are only a few individuals from three other hamlets who are contributing to tourism development which means CBT cannot meet each individual need within the community."

Issues related to fulfilling individual's needs in the village, therefore, appeared as the result of unequal distribution of benefits within community members, and a need to potentially enhance individuals' self-fulfilment by evenly distributing benefits within the community.

In the cultural context, CBT practices directly increased the effort to bring back obsolete art and cultural performance, including traditional dances, traditional Javanese music, rites, and traditional ceremonies that enhance the rebuilding of community identity and culture. As revealed by the local tour guide, CBT practices have cultural impacts on their ancient art and cultural activities:

"Art and cultural attractions become tourist attractions in this village. That means our culture is being recognised by tourists. They are even interested in following the art and cultural activities. It is the time to show them our identity. Tourism can be beneficial in strengthening our identity."

In the cultural aspect context, all respondents interviewed stated CBT practices directly increased the effort to revive art and cultural performance such as traditional dances, traditional Javanese music, rites, and traditional ceremony. Increasing demand for a more authentic form of cultural tourism in the village made the community aware of their cultural assets. However, several changes were made to some art and cultural activities which impacted their 'sacredness'. They usually shorten the duration of religious rites without deeper religious practice because we consider that tourists are coming from many different religious backgrounds.

\section{DISCUSSION AND CONCLUSION}

CBT development in the village increased the local income that directly benefited some members of the local community. Such a situation inevitably created an uneven distribution of opportunities to participate in the planning and development of tourism due to the wide range of roles and profiles within the village. As power relations can determine community members' involvement in tourism activities [6], the job distribution and community involvement in the village thus highly depended on the individual's social capital. The local community tourism organisation as an overarching body of tourism development activities directly encouraged a situation in which the power relations between the organisation and high-competence individuals determined the successfulness of development outcomes [2]. This institutional arrangement in which the local tourism organisation appeared as the main regulator of development [51] resulted in community conflicts that were mainly caused by uneven participation opportunities between individuals and benefits they received from tourism development. Therefore, the local power relationship in the village was potentially factional [26] separating those who lacked social capacity and capital from development [29] from the ones who were able to participate. Thus, CBT practices in the village indirectly marginalised some individuals in the village who had lesser social and cultural capital and therefore not able to participate and gain benefits from tourism activities.

It is important to notice that in achieving maximum profits through the development of $\mathrm{CBT}$, community empowerment through tourism can result in taking more time [6]. In the Nglanggeran Tourism Village, the practices of CBT are mainly driven by economic motivation such as job creation and income generation which in turn can potentially challenge the local tourism organisation in enabling equal distribution and empowerment of all members of the village. Similar to a previous study that examining the empowerment of the local community through CBT in four rural communities in Peru [39], CBT practices in the village encouraged the community's economic self-reliance by providing and creating more local employment opportunities alongside the growth of CBT in the village. It also generated more social problems including uneven participation opportunities between local community members in regard to the control of CBT.

The community found obstacles in harmonising their perspectives about tourism planning and development, such as having some local community members who did not aim to follow tourism development because of their willingness to retain their existing livelihood practices. Occasionally, the whole community 
participating equally in the planning and management of the village was perceived as time-consuming and costly. Additionally, the transformation of community livelihood from a farming and agriculture-based economy into tourism was rejected by some individuals in the village from Doga and Karangsari hamlet, potentially diminishing the development of CBT in the related areas.

Culturally, some ancient community's cultural assets were commodified through the development of CBT in the village by including them as tourism attractions. Such cultural commodification generated more income for the local community through transactional activities. On the other hand, the commodification of cultural performances influenced how the community perceived its culture as a commodity that potentially resulted in the loss of their cultural sacredness. It leads to diminishing their attractiveness for tourists that resulted in fewer tourists attracted to the area and fewer economic benefits that the community could gain from tourism activities.

From the environmental conservation perspective, CBT practices in the village were successful in increasing the environmental conservation efforts, such as the Clean Friday initiative. The local community tourism organisation took the right to control the visitation along with including the environmental cost in their pricing. Although the pricing strategies used for cultural performances were increased to limit the number of visitors in the village, as well as re-planting trees and vegetation surrounding the tourism village area, the total revenue from tourism activities got increased.

The effort to assess the compatibility of CBT development practices in Nglanggeran Tourism Village with sustainable community development additionally raises a question regarding cultural identity development in the village. By enabling cultural transactions between hosts and guests, mutual interactions between the supply and demand sides of tourism can generate a tourism culture in the village as a new distinctive emergent culture that is shaped by local communities and shapes the local tourism context [34]. The local community's culture of the Nglanggeran Tourism Village is slowly transforming itself into a tourism culture which in turn potentially becomes the new local community identity. Some local community members performed regular traditional ceremonies such as Kenduri to fulfil the tourists' desire for authenticity by providing a tourism version of traditional dances that were regularly performed in several traditional village ceremonies. The community also perceived that their traditional clothes convey specific meanings. Therefore, they use them as a tour guide uniform, encapsulating a new community tourism identity emerging with local tourism development.

Practically, to overcome the developmental challenges of $C B T$ in the village, in particular, the CBT impacts on community economic well-being, socio-cultural development, and environmental sustainability, local tourism planners could consider community participations' operational, structural and cultural limits [52] when developing $C B T$ in the village. The present development stage of CBT in the Nglanggeran Tourism Village is compatible with the spontaneous participation phase [53] in which several community members appear as the main actors for development with some of them having a deeper understanding of tourism planning and development than others.

In achieving sustainable development, locallevel participation is important to be considered, but such participation potentially encourages a shift of power from local authorities to local actors [53]. Moreover, true local control desired by local communities is difficult to be realised in the village considering that CBT practices are only managed and organised by a group of people with regard to their social and cultural capital in the village. In the future, using the research result as a basis, a series of educational training sessions in managerial aspects of the environment and visitor management of CBT experience in the village could be initiated by the local government to give equal basic training in tourism for the local community, particularly for those who lack social capacity and capital from tourism development. In that regard, further research would be required to critically examine whether such a model of CBT in various other Indonesian village tourism destinations leads to a critical and emancipatory approach for sustainable community development.

\section{REFERENCES}

[1] Jones, S. 2005. Community-based ecotourism: The significance of social capital. Annals of Tourism Research 32(2), 303-324. 
[2] Manyara, G. and E. Jones, 2007. Community-based tourism enterprises development in Kenya: An exploration of their potential as avenues of poverty reduction. Journal of Sustainable Tourism 15(6), 628-644.

[3] Bello, F. G., B. Lovelock, and N. Carr. 2017. Constraints of community participation in protected area-based tourism planning: the case of Malawi. Journal of Ecotourism 16(2), 131-151.

[4] Gascón, J. 2013. The limitations of community-based tourism as an instrument of development cooperation: the value of the Social Vocation of the Territory concept. Journal of Sustainable Tourism 21(5), 716-731.

[5] Byczek, C. 2011. Blessings for all? Community-based ecotourism in Bali between global, national, and local interests-a case study. Austrian Journal of South-East Asian Studies 4, 81-106.

[6] Blackstock, K. 2005. A critical look at Community-Based Tourism. Community Development Journal 40(1), 39-49.

[7] Litka, S. 2013. The Maya of Cobá: Managing tourism in a local Ejido. Annals of Tourism Research 43(2), 350-369.

[8] Hampton, M. P. and J. Jeyacheya. 2015. Power, ownership and tourism in small islands: Evidence from Indonesia. World Development 70(3), 481-495.

[9] Hitchcock, M. 2001. Tourism and total crisis in Indonesia: The case of Bali. Asia Pacific Business Review 8(2), 101-120.

[10] Sugiyarto, G., A. Blake, and M. T. Sinclair. 2003. Tourism and globalization: Economic impact in Indonesia. Annals of Tourism Research 30(3), 683-701.

[11] Ministry of Tourism and Creative Economy International Labour Organization (ILO). 2012. Strategic plan for sustainable tourism and green jobs for Indonesia. International Labour Organization, Indonesia Office. Jakarta.

[12] Republic of Indonesia. 2011. Government Regulation of Republic of Indonesia No. $50 / 2011$ on the National Tourism Development Master Plan 2010-2025. State Secretary. Jakarta.

[13] Ristiawan, R. R. 2018. Culture as tourism attraction: commodifcation and politicization of culture in Kembangarum Tourism Village, Yogyakarta Special Region,
Indonesia. Gadjah Mada Journal of Tourism Studies 1(1), 12-22.

[14] Nuryanti, W. and W. G. Hwang. 2002. Private and public sector partnership in tourism development. Gadjah Mada University Press. Yogyakarta.

[15] Ristiawan, R. R. 2019. A critical perspective of the unique selling point for sustainable tourism development: Pentingsari Tourism Village. Gadjah Mada Journal of Tourism Studies 2(1), 45-53.

[16] ASEAN. 2017. Nature based tourism: ASEAN sustainable tourism awards. Available at: http://aseantourism.travel/media/kcfinder/ docs/ASTA_booklet_a5_FA18-Jan(1).pdf.

[17] Berkes, F. 2004. Rethinking communitybased conservation. Conservation Biology 18(3), 621-630.

[18] Mathie, A. and G. Cunningham. 2003. From clients to citizens: asset-based community development as a strategy for communitydriven development. Development in Practice 13(5), 474-486.

[19] Ruiz-Ballesteros, E., and R. Cáceres-Feria. 2016. Community-building and amenity migration in community-based tourism development: an approach from Southwest Spain. Tourism Management 54(3), 513523.

[20] Zapata, M. J., C. M. Hall, P. Lindo, and M. Vanderschaeghe. 2011. Can communitybased tourism contribute to development and poverty alleviation? Lessons from Nicaragua. Current Issues in Tourism 14 (8), 725-749.

[21] Sharpley, R. and D. J. Telfer. 2015. Tourism and development in the developing world. Routledge. London.

[22] Tolkach, D. and B. King. 2015. Strengthening community-based tourism in a new resource-based island nation: Why and how? Tourism Management 48(3), 386-398.

[23] Simons, I. and E. de Groot. 2015. Power and empowerment in community-based tourism: opening Pandora's box? Tourism Review 70(1), 72-84.

[24] Keyim, P. 2018. Tourism collaborative governance and rural community development in Finland: The Case of Vuonislahti. Journal of Travel Research 57(4), 483-494.

[25] Snyder, K. A. and E. B. Sulle. 2011. Tourism in Maasai communities: A chance to improve livelihoods? Journal of Sustainable Tourism 19(8), 935-951. 
[26] Salazar, N. B. 2012. Community-based cultural tourism: issues, threats and opportunities. Journal of Sustainable Tourism 20(1), 9-22

[27] Farrelly, T. A. 2011. Indigenous and democratic decision-making: issues from community-based ecotourism in the Boumā National Heritage Park, Fiji. Journal of Sustainable Tourism 19(7), 817-835.

[28] Goodwin, H. and R. Santilli. 2009. Community-based tourism: A success. ICRT Occasional Paper 11(1), 37.

[29] Sood, J., P. Lynch, and C. Anastasiadou. 2017. Community non-participation in homestays in Kullu, Himachal Pradesh, India. Tourism Management 60(3), 332-347.

[30] López-Guzmán, T., S. Sánchez-Cañizares, and V. Pavón. 2011. Community-based tourism in developing countries: A case study. Tourismos 6(1), 69-84.

[31] Pavlić, I. and A. Portolan. 2015. Irritation Index, Tourism. In: Jafari, J. (Ed). Encyclopedia of Tourism. Springer International Publishing. New York. 1-2.

[32] Picard, M. 2003. Touristification and Balinization in a time of reformasi. Indonesia and the Malay World 31(89), 108118.

[33] Belhassen, Y., N. Uriely, and O. Assor. 2014. The touristification of a conflict zone: The case of Bil'in. Annals of Tourism Research 49(2), 174-189.

[34] Canavan, B. 2016. Tourism culture: nexus, characteristics, context and sustainability. Tourism Management 53(2), 229-243.

[35] Cole, S. 2007. Beyond authenticity and commodification. Annals of Tourism Research 34(4), 943-960.

[36] Bao, J. and M. Lin. 2014. Study on control of tourism commercialization in historic town and village. Acta Geographica Sinica 6(2), 268-277.

[37] Tiberghien, G., H. Bremner, and S. Milne. 2017. Performance and visitors' perception of authenticity in eco-cultural tourism. Tourism Geographies 19(2), 287-300.

[38] Tiberghien, G. 2018. Managing the planning and development of authentic eco-cultural tourism in Kazakhstan. Tourism Planning and Development, 1-20.

[39] Knight, D. W. and S. P. Cottrell. 2016. Evaluating tourism-linked empowerment in Cuzco, Peru. Annals of Tourism Research 56(1), 32-47.
[40] Richards, G. and D. Hall. 2003. The community: A sustainable concept in tourism development? In: Richards, G. and D. Hall (Eds). Tourism and sustainable community development Vol. 7. Psychology Press. London. 1-14.

[41] Nozick, M. 2000. Sustainable development begins at home: community solutions to global problems. In: Pierce, J.T. and A. Dale. (Eds). Communities, Development and Sustainability Across Canada. UBC Press. Vancouver. 1-26.

[42] Murphy, P. E. 2013. Tourism: A community approach (RLE Tourism). Routledge. London.

[43] Parmawati, R., W. Wike, and E. Pangestuti. 2019. The involvement of women in tourism village of Pujon Kidul, Malang, Indonesia. Journal of Indonesian Tourism and Development Studies 7(2), 120-130.

[44] Park, E. and S. Kim. 2016. The potential of Cittaslow for sustainable tourism development: enhancing local community's empowerment. Tourism Planning and Development 13(3), 351-369.

[45] Xue, L., D. Kerstetter, and C. Hunt. 2017. Tourism development and changing rural identity in China. Annals of Tourism Research 66(2), 170-182.

[46] Yin, R. K. 2009. Case study research: Design and methods, $4^{\text {th }}$ Ed. Sage Publications. Thousand Oakes, CA.

[47] Phillimore, J. and Goodson, L. 2004. Qualitative Research. In Phillimore, J., Goodson, L (eds). Tourism: Ontologies, Epistemologies and Methodologies Vol. 14. Psychology Press. London.

[48] Donmoyer, R. 2000. Generalizability and The Single-Case Study. In: Gomm, R (Ed). Case Study Method: Key Issues, Key Texts. Sage. London. 45-68.

[49] Fereday, J. and E. Muir-Cochrane. 2006. Demonstrating rigor using thematic analysis: A hybrid approach of inductive and deductive coding and theme development. International Journal of Qualitative Methods 5(1), 80-92.

[50] Department of Tourism, Daerah Istimewa Yogyakarta. 2015. Tourism Statistics Book Daerah Istimewa Yogyakarta. Department of Tourism, Daerah Istimewa Yogyakarta. Yogyakarta.

[51] Li, T. M. 2007. The will to improve: Governmentality, development, and the practice of politics. Duke University Press. Durham, NC. 
[52] Tosun, C. 2000. Limits to community participation in the tourism development process in developing countries. Tourism Management 21(6), 613-633.

[53] Tosun, C. 2006. Expected nature of community participation in tourism development. Tourism Management 27(3), 493-504. 